\title{
Echoic Representations of Two Feminist Models of Women: The Industrious Rosie 'the Riveter' and the Eccentric Frida Kahlo
}

\author{
María del Mar Rivas-Carmona ${ }^{1} \&$ Manuel Balsera-Fernández ${ }^{1}$ \\ ${ }^{1}$ Faculty of Philosophy and Arts, Córdoba, Spain. \\ Correspondence: María del Mar Rivas-Carmona, Faculty of Philosophy and Arts, Córdoba, 14071, Spain.
}

Received: October 6, 2015

Accepted: October 19, 2015

Available online: October 26, 2015

doi:10.11114/ijsss.v3i6.1171

URL: http://dx.doi.org/10.11114/ijsss.v3i6.1171

\begin{abstract}
This paper focuses on iconic language as an intense, multimodal way of communication, and, more concretely, on representations endowed with an 'echoic nature' that have had the power to convey deeply emotional and persuasive messages in different contexts. After briefly reviewing the various epistemological approaches that have dealt with symbolism in art, two images of archetypal women, repeatedly recreated in various sorts of locative and temporal spaces, will be analysed from the pragmatic-cognitive perspective of Sperber \& Wilson's Relevance Theory (1986, 1995). The first echoic representation has its source in a poster with one of the most well-known faces of US propaganda, Rosie Will Monroe's, calling for women's work effort in order to help their country win the war, with the moving advertising slogan "We can do it". The other model is based on the image of Frida Kahlo who won fame with her pictorial work, in spite of being partially eclipsed by her famous husband, the Mexican muralist Diego Rivera; the portrayal of her "long-suffering self" (egotistical echoicity) and her polemic and eccentric biography turned her into an icon of art, revolution and feminism.
\end{abstract}

Keywords: iconic language, echoic representation, multimodal communication, feminism, Rosie the Riveter, Frida Kahlo

\section{Introduction: The relevance of symbolic repertoires}

In contemporary philosophy, symbolic thinking1 has been the object of study of different hermeneutic approaches derived from Ernst Cassirer's philosophy of 'symbolic forms' (1953), as well as that by Hans G. Gadamer, Gilbert Durand or the Swiss school of Eranos. Also relevant are the irrationalist approaches, mainly the one expounded by F. Nietzsche, for whom symbolism and metaphor, in particular, are the perfect instruments not only for apprehending reality, but also for highlighting and enhancing its authentic and essential aspects (Benne, 1969). The symbolist movement conceives art in a very similar way, as they believed that symbols (as public representations) were the only way to express what they felt and experienced as individuals.

Art, as a symbol, is of an inherently referential nature2. Cassirer's philosophic anthropology (1944) stated that the symbolic system was the distinguishing feature of human beings. Gadamer (1986) goes back to the original meaning of the term 'symbol' as a tessera hospitalis, or a little piece of board that hosts gave their guests as a sign of hospitality, so that they could recognize their friendship in the future when they put the pieces together again. This 'symbol' was a witness of the past that brought it to life again, in the same way as the meaning of a work of art refers back to something that cannot be immediately comprehensible. A symbol represents and may even substitute its referent, attracting the attention or devotion that the referent should receive. Nevertheless, the portions of reality art 'extracts' are not offered to a passive observer, but demands an active contribution from this.

For both Cassirer and Gadamer, symbols move us away from crude sensations; if ordinary sensory perception is limited by the characteristics of the senses, aesthetic perception is enriched by its infinite possibilities of choice and combination of entities and relations. For this reason, a work of art transcends time and remains alive for centuries after its conception. In Montero-Pachano's words (2005): "Como las almas divididas en el mito que Platón adjudica a Aristófanes, el artista busca y encuentra su símbolo indefinidamente." ["Like the divided souls in the myth Plato ascribes to Aristophanes, the artist seeks and finds its symbol indefinitely".] 


\subsection{Peirce's contribution: 'aliquid stat pro aliquo'}

The contribution by Peirce (1839-1914) to the study of symbols is also of fundamental importance (Houser et al., 1992). $\mathrm{He}$ is considered as the founder of pragmatism and the father of modern semiotics; he distinguished between signs of nature, which are unintentionally emitted, and signs of the individuals, which are intentional and shared by the community. According to Peirce (1958), the indirect, motivated, non-arbitrary character of the sign makes it an object for another process of meaning, that is, makes it a 'third' element. As opposed to Saussure, who studied the linguistic sign, Peirce analysed men's relationship with the world: his semiotic philosophy is based on the universal categories of perception and the opinion that, although 'every thought is a sign', its meaning becomes a new sign once created in another person's mind with an equivalent or more developed character than the original one. For Peirce, a sign is something that stands on behalf of something else for someone (aliquid stat pro aliquo).

According to Peirce, signs can be divided up into several types based on the relationship the sign maintains with its object:

- ICON: when there is a direct relationship of similarity, with a concrete purpose or intention. For Peirce, the icon is the only sign that can be subdivided into:

a) metaphors,

b) schemes, maps, organigrams, synoptic charts, sketches, and

c) hypoicons: specifically for images;

- INDEX: symptoms or hints without any communicative intention that a person can interpret thanks to his/her knowledge of the world. There is a cause-effect relation between the phenomena (smoke-fire; fever-illness);

- SYMBOL: the relation between sign and object is indirect, i.e., conventional and intentional.

These different types of signs can be combined in various ways: iconic-indicative, iconic-conventional, etc. The sign categories of firstness, secondness and thirdness define the posible ways in which the knowledge of the world may be accessed, in this precise order: 'possibility', 'existence' and 'law'. For Peirce, the symbol is a type of sign which denotes an object according to a convention, by virtue of a general law that makes us associate ideas in that way. The signs interrelate within themselves, with the interpreters and the objects, establishing syntactic, pragmatic and semantic levels.

Peirce (1958) set up a semiotic model of communication (the so-called triadic logic) which established that:

1. the object or referent refers to the reality that can be accessed through the sign [existence];

2. the representamen or sign acts as a symbolic system (it is never the object in its entirety) [possibility]; once we know the sign, we can infer its meaning. - This concept of peircean inference is the pioneer step leading to cognitive pragmatics (the construction of meaning)-, and

3. the interpreter, that alludes to the knowledge produced in the mind [law].

Thus, the representamen and the interpreter are mental entities that act as symbolic operations in order to understand the world. Peirce concludes that the meaning of a representation has to be another representation, anticipating the later concept of meta-representation3 (the representation of another representation), fully developed by Dan Sperber and Deirdre Wilson (1986, 1995). Each interpreter is a cultural unit (convention), so s/he could give rise to an unlimited semiosis (ad infinitum) -a term used by Umberto Eco in his hermeneutics of the chains of interpreters-, since the interpreter becomes, at the same time, a sign, i.e. "x stands on behalf of and for z". The interpreter is a product we elaborate, not the thing-in-itself, but the thing-for-us; it is the referent turned into a cultural unit, processed and modified by the conventions and rules of society.

Peirce's conception of semiosis as a complex fabric of unlimited signs in movement will provide us with the key to interpreting the sign process in the Net, which has been the source for the illustrations here analyzed. The use of the 'triad' to explain semiosis, the division of signs, the division of semiotics, or the most simple communicative model, has been very productive for a long period of time. In fact, this theory has had many continuators, such as Charles Morris (1971), for whom the human being is essentially a 'symbolic animal', and Umberto Eco, who tackles the sign (its meaning, classification, structure, etc.) in Il segno (1973).

\subsection{Morris's contribution: the binding of meaning, users and use}

The American philosopher Charles Morris (1901-1979) defined pragmatics, within the frame of semiotics, as a triad divided up into three levels:

a) the syntactic level (the formal relation between the signs and their grammatical structure); 
b) the semantic level (which establishes the relationships of meaning), and

c) the pragmatic level (the relationship between the signifiers and those who use the signs, as well as the use of those signs). His binding meaning and use meant a sharp distinction from pure linguists.

If the other components of language are governed by rules, pragmatic elements are governed by principles, such as Grice's Principle of Cooperation (sociology) -which Sperber \& Wilson (1986, 1995) do not consider to be absolutely necessary for communication-, or Sperber \& Wilson's Principle of Relevance (individual psychology), whose basic purpose lies in its cognitive (knowledge) and communicative (interaction) goals. When the code is not very precise, something frequent in human interaction, communication relies almost exclusively on inferences, which implies making intuitive predictions and gradual interpretations along a scale of probability. Non-linguistic utterances have no explicatures (ostensive inferences), which are always linguistic, but only implicatures.

\subsection{Eco's contribution: the poetics of the open work}

Umberto Eco, who continued Peirce's work, conceives the sign as an entity employed to transmit information, and states that the mystic "referent" is an extra-semiotic entity (signs function and mean apart from their relationship with a real referent). For Eco (1973), the sign is like a homonym word that can be used on different occasions with different senses, and, generally, in such a metaphoric vague way (the poetics of signs) that it may provoke "aberrant decodifications".

In his work La struttura assente (1968: 212), he includes a chart on the possible aberrant decodifications in mass communications which explains that, in this model, when the addresser does not solve the ambiguity in a message or is not able to follow all the acts of fidelity in order to reach the addressee's codes (because of a lack of knowledge or other deviating circumstances), s/he turns to private codes and introduces random connotations. He also proposes a kind of 'semiologic guerrilla warfare' which shows that the message is an empty recipient only filled with meaning by the interpreters themselves, who get this meaning from the cultural universe surrounding them. Thus, Eco rejects the following:

a. that this semiotic category has the same properties as the object it is related to;

b. that the iconic sign is similar to its object;

c. that there exists a relationship of analogy between them;

d. that the icon is motivated by the object.

Accordingly, he concludes that the signs function and mean apart from their relationship with a real referent.

Eco (1973) also advocates the validity of the symbol as a means to communicate 'the indefinite', which is open to new reactions and interpretations. Hence, he proposes 'the poetics of the open work' (opera aperta) as opposed to 'the poetics of the univocal and the necessary'. The latter equals the Medieval artist's finished unidirectional work (the work built as an indisputable pedagogical message with a single option of meaning) which reflects a conception of the cosmos as a strict hierarchy, i.e. the general tendency in our culture. As opposed to this, the poetics of the 'open work' resembles the Classical world, understood as being a field of infinite possibilities, not as a lack of definition (man is not subject to canons). This is the poetics of surprise, inventiveness, metaphor and suggestion, and the work of art is an object to research into.

\subsection{The work of art as an object to research into}

Let's illustrate all these contributions with the example of a well-known portrait by the American painter Grant Wood that has led to the creation of a great number of relevant echoic representations, 'American Gothic' $(1930)^{4}$. As Corn put it in "The Birth of a National Icon: Grant Wood's 'American Gothic'” (1983), the painter's primary intention was to present the sphere of the farmer's in a satirical way, but, with the passing of time, the work has become an icon representing the main family values of deep America: White, Anglo-Saxon, Protestant (WASP). The conservative family is structured around the figure of a strict father who strongly believes in the need and value of authority, who teaches his children to discipline themselves and fight in a competitive world where they will succeed only if they stay strong, assertive and disciplined. 


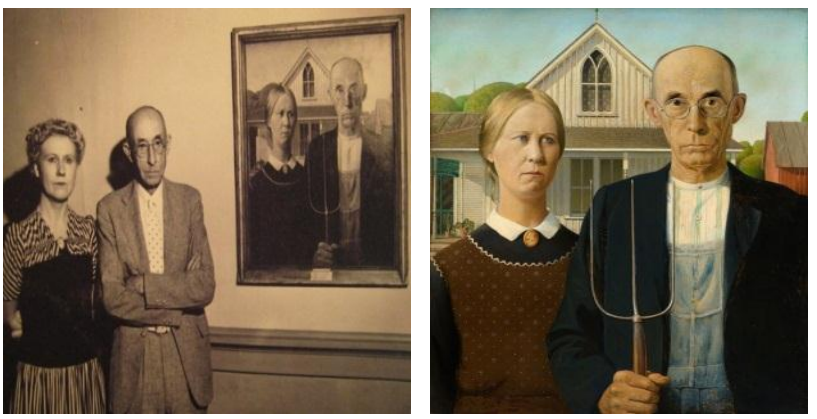

Figure 1. Nan Wood and Dr. Byron McKeeby pose next to ‘American Gothic' by Grant Wood (1930)

Figure 2. 'American Gothic' by Grant Wood (1930)

Grant Wood painted American Gothic in 1930, and used his sister Nan (1900-1990) and his dentist, Dr. Byron McKeeby (1867-1950), as real models, which seems to confirm Eco's statement that the mystic referent is an extra-semiotic entity. The painting portrays a farmer, who is holding a hayfork, and an American midwest woman, both in front of a Gothic-style house in the country. It would seem that the painter intended to symbolically represent the traditional male and female roles (social convention); nevertheless, he provokes ambiguity, understood as a field of probabilities, from the most basic level of interpretation, namely, the relationship between the characters: are they husband and wife, or father and daughter? The image can also be used as the basis to comment on a great variety of topics, such as the family, puritanism, ethic work, individualism, their propriety, the common features of men and women in the country areas, or all of these topics together in a holistic combination. This permits an unlimited semiosis (ad infinitum), as the interpreters become a sign themselves. In fact, American Gothic is one of the most popular 20th c. American art images and has led to innumerable pragmatic-cognitive and anthropological "echophanies" (echoic representations) (BalseraFernández, 2012; 2013).

\section{Research method: Relevance Theory and Multimodal Communication}

From a pragmatic-cognitive and anthropological perspective, it is evident that there is not one 'mode' of communication only. In other words, verbal language is not the only means of transmitting a message; far from it, communication is essentially multimodal.

We agree with Sperber's (1975) premise that individuals possess inborn 'archetypes' that allow them to interpret each symbolic piece of information in itself, as symbolism is a productive faculty as well as a creative ability. For him, symbolism is a cognitive, not a semiological, system. From his cognitive stand, the symbolizing and signifying process is not restricted to the level of the code, but takes place when the code effectively encounters the communicative context (Weinberg de Magis, 1998). The concept of symbol is a secondary cultural development of the universal phenomenon of symbolism. The notion of symbol is, then, cultural, not universal; varying from one culture to another, or even within the same culture. A symbol may have diverse interpretations depending on the cultural contexts in which it occurs and these contexts are built upon expanding mental processes, which Sperber (1996) terms an "epidemiology of the representations", since they transmit like viruses.

Sperber conceives symbolism as a cognitive process, which is the product of a "symbolic function" of the human mind in which two mechanisms are associated: a) the conceptual device, which builds the concepts scientific knowledge is based on, and b) the symbolic device, a cognitive one that collaborates in the construction of knowledge and the functioning of memory. It must be borne in mind that most of today's cognitive scientists agree on the fact that knowledge consists of mental representations, i.e., individual mental forms about the world around us (Dawson, 1998; Sobel, 2001; Thagard, 2005; Pinker, 2007). Mental associations made in our symbolic constructions are of a metaphorical kind, which implies that symbolic associations are established on the basis of interpretative vicinity, proximity and similarity, not on the necessary existence of an underlying system of signs (code) underneath every form of organized social behavior (Sperber \& Wilson, 1986, 1995; Wilson \& Sperber, 2004).

Sperber \& Wilson's Relevance Theory (RT onwards) $(1986,1995)$ is considered as being one of the fruitful approaches to the study of the transmission of multimodal messages. It states that communication is governed by imperfect heuristics. Relevance arises from the relationship between the utterance, the individual and the concrete situation. The concept of relevance is interrelated with the concept of context as a psychological construction (a subgroup of the pre-supositions about the world of the addressee at a particular moment). Thus, communication is not a finished, but a gradual process.

According to RT, genuine communication is ostensive-inferential communication (open communication), although, as 
the ordinary pragmatic reality shows, very frequently communication is covert, that is, there is an emotional use of reference in order to obtain bigger "contextual effects" (Tanaka, 1994; Sperber and Wilson, 1995). Every communicative event consists of two interpretation processes: one goes from the 'mental' to the 'public', and the other, from the 'public' to the 'mental' (Sperber, 1996). A mental representation is produced in the user's mind (a memory, a belief, an intention), whilst a public representation may have a producer and various users. A public representation is a process of shared cognition which involves social immersion and exchanges between the participants. Public expressions, such as signs, texts, pictures, narratives, stories, graphic-schematic representations, causal chains, etc. can be interpreted because there are underlying systems (a language, a code, an ideology) and the users can make probabilistic or inferential hypotheses -imperfect heuristics. As for cultural representations, they are generalized and lasting representations, composed of a group (many versions) of both mental and public representations.

A message producing weak implicatures requires a bigger processing effort, but, in contrast, achieves more "cognitive effects". It is the interpreter/observer's task to discover what the images, as symbolic vehicles of ideas, symbolize. When trying to interpret them, the addressees will revise their hypotheses and elaborate them from their previous expectations, following a series of sub-tasks (Wilson \& Sperber, 2004: 261):

- constructing an appropriate hypothesis about explicit content (explicatures)

- constructing an appropriate hypothesis about the intended contextual assumptions (implicated premises)

- constructing an appropriate hypothesis about the intended contextual implications (implicated conclusions)

\section{Analysis of the corpus}

As stated above, the present study focuses on the concept of echoicity, understood as being an echoic-orchestral dialogue produced between the visual patterns and their replicas, with specific and 'cronetic' (opportunity in time) communicative goals, not necessarily simultaneous (which would imply some kind of co-presence) that would function as 'reviviscences' of the original (see Balsera-Fernández, 2013). Each of these replica representations is called an "echophany" or echoic manifestation with a communicative nature; they are clearly distinguished from spin offs (derived or secondary products) and similar to replicas or knockoffs, produced by active addressees who, with their own interpretations, create an unusual series of polarized meta-representations. This is related to the Sperberian concept of 'echoic mention' (Sperber, 1984).

The echoic representations under focus in this study are related to two different, but equally inspiring, feminist models of women: Rosie the Riveter and Frida Kahlo.

\subsection{Ecophanic representations of the industrious and hard-working Rosie 'the Riveter'}

World War II was a crucial event that served to put women on a level with men as a labour force. Men had to do their military service and left a large number of empty posts that women were able to fill. By the end of the conflict, the amount of employed women in the US reached almost 18 million, practically a third of the total labour force. Nevertheless, the return to normality had a great effect on these women; the men who came back from the battlefield resumed their jobs and many women were dismissed or hired for more "feminine" tasks of housework, or as secretaries and office workers.

The efficient, brave and tireless women workers who had appeared in posters and magazines throughout the war continued to be praised even when they were not the prevailing paradigm any more. The most inspiring image was that of "Rosie the Riveter", whose real name was Geraldine Hoff Doyle. Not many people may remember Doyle, but they would remember Rosie, a fact that serves us to corroborate Eco's statement that the mystic referent is an extra-semiotic entity. The name Rosie was taken from the song "Rosie the Riveter"5 written by R. Evans and J. Loeb in 1943, praising these bold women workers. The Westinghouse Power Company entrusted the artist J. Howard Miller with the painting of the poster, in order to raise its workers' morale.

As Penny Colman explains in Rosie the Riveter: Women Working on the Home Front in World War II (1998), there were other cultural icons as popular as Rosie, like Wendy the Welder, inspired in Janet Doyle, a worker at the Kaiser shipyard in Richmond, California, or Julie the Janitor, a worker at the Eastern Illinois University; nevertheless, none of them became as popular as Rosie. 


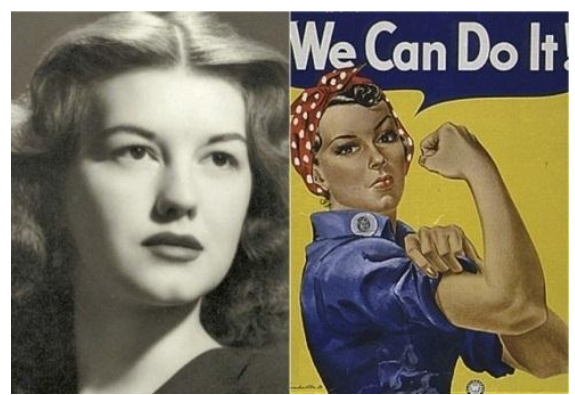

Figure 3. Geraldine Hoff Doyle, model for Rosie's poster

Figure 4. 'Rosie the Riveter' by J. Howard Miller (1943)

The woman with the polka-dot headscarf who rolls up her sleeves to show her muscles while she exclaims with an air of determination: "We can do it!", was not exactly created in order to "empower" their country at a time of conflict.

In her article "Rosie la Remachadora: la verdadera historia que esconde el icono del feminismo" ["Rosie the Riveter: the true story behind the icon of feminism"] (2014), López-Alonso wondered why a 1943 illustration was still inspiring the world. The echoic strength of this image is so powerful, indeed, that it is the source of many current poetic and artistic representations. Let's use as an example Tamas Gaspar's illustration recently appearing in "deviantART.net" (dA), a Web site which brings together international artists, critics and analysts from all the world.

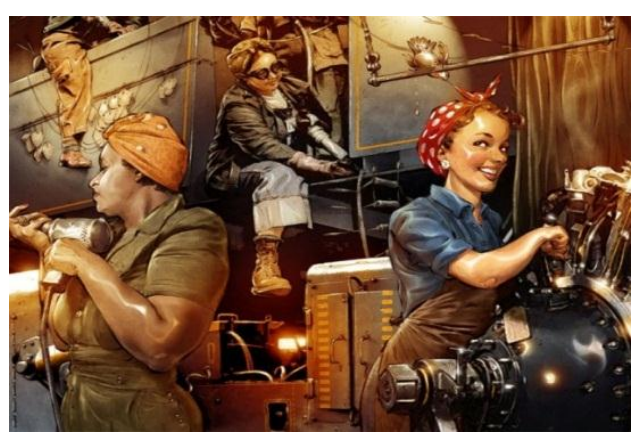

Figure 5. 'Rosie the Riveter' by Tamas Gaspar (2009)

URL: <http://fc00.deviantart.net/fs49/f/2009/177/f/6/Rosie_the_Riveter_by_TamasGaspar.jpg>

According to López-Alonso (2014), "La imagen de Rosie ha sido absorbida por la cultura popular occidental, pasando a convertirse en una figura ligeramente exenta de significado" ["Rosie's image has been absorbed by Western popular culture, becoming a slightly meaningless figure"]. On the contrary, we defend its useful echophanic power, as the following examples will show:

\subsection{1. 'Rosie the Riveter' and 'American Gothic': a call for true patriots}

As explained above, Grant Wood's picture 'American Gothic' (1930) (see Fig. 2) represented the national allegory of the American family during the war. In the echophanic reproduction of this picture below (Fig. 6), it is combined with two other American popular symbols, Rosie the Riveter and Uncle Sam. As it is well-known, Uncle Sam is the personification of the US. In fact, the image drawn by James Montgomery Flagg with the caption "Uncle Sam needs you" is probably the most popular incitement to recruitment. Women, whose husbands, brothers and sons had been called up to the front in order to defend their country, contributed with their work so that the military system would not collapse due to a lack of labour? 


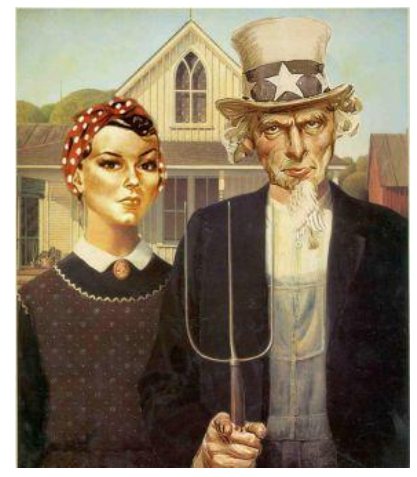

Figure 6. 'American Gothic' parody: Rosie the Riveter and Uncle Sam (2015)

\section{URL: <https://es.pinterest.com/screenstarr/american-gothic/>}

URL: <http://www.jigidi.com/solve.php?id=DFXOJYZE>

Most addressees of this picture will not require a hard processing effort in order to interpret the addresser's intention. Their shared knowledge of the world and of popular American symbols will help them in their interpreting process.

The explicit content of the picture recalls that of Wood's 'American Gothic'. Most of the elements are preserved, except for two particularly meaningful ones: the protagonists' heads and the man's hand are different. In this case, the woman's face is not Nan Wood's, but Rosie's with her polka-dot red kerchief, and the man's face is not Dr. McKeeby's, but Uncle Sam's, who is also pointing at the picture's audience.

The implicated premises of the message lie in the fact that the American audience will easily recognize the well-known archetype representing the values of the American family and citizenry symbolized by 'American Gothic'. These values are further 'reinforced', as they are 'fused' with two even more popular 'personifications', those of Uncle Sam and Rosie the Riveter.

Had this picture appeared at a time of conflict, the implicated conclusions drawn from the image would have amounted to a call to serve the country, probably summarized as follows: "your country needs you, be good citizens; you, man, defend your country at the front, while you, woman, work here on the home front." The protagonists' direct penetrating looks and Uncle Sam's straight finger pointing at the viewer contribute to the persuasive, almost intimidating tone of the message, as if warning: "If you don't contribute, you're not a real American patriot...". Nevertheless, the fact that this echoic picture is a recent and amusing parody of American Gothic, even appearing in the form of an 80 piece puzzle, leads us to the conclusion that the author chose such an extremely popular topic just for the sake of recalling truly patriotic icons that the audience would easily recognize, and whose combination they would find amusing.

3.1.2. 'Rosie': from a hard-working worker to a brave soldier on the front

Things have evolved with the passing of time and women now claim the right to fight on the front lines. In spite of the fact that women have served in the American army since 1775, their leading roles only consisted of supporting men as nurses, seamstresses, cooks or cleaners. Nevertheless, women now represent almost $14 \%$ of the US army and, with the new policies introduced in 2012, they are gaining ground. This is, of course, a controversial issue, as there is no consensus on women going into combat; it is also a subject for discussion in classes and seminars, where feminist and patriotic symbols, such as that of Rosie the Riveter, are analyzed.

There is also an ideological current in journalists and cartoonists who address these polemical issues and express their values of Independence, neutrality and objectivity in different socio-cultural, temporal and geographic contexts. The next two cartoons, echophanies or re-elaborations of the original Rosie the Riveter poster, are a good example of this. The first cartoon (Fig. 7) was drawn by the editorial cartoonist Adam Zyglis for the New York Buffalo News and the second one (Fig. 8) by Steve Benson for The Arizona Republic. 

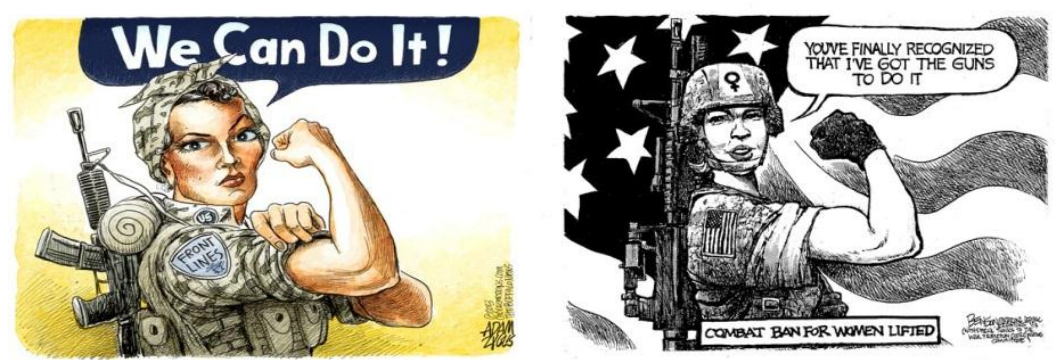

Figure 7. 'Women in the military', New York Buffalo News, by Adam Zyglis (2013)

URL: <http://www.cagle.com/2013/01/women-in-the-military/>

Figure 8. 'Women in combat', The Arizona Republic, by Steve Benson (27/02/2013)

URL: <http://www.cagle.com/news/women-in-combat/>

The explicit content in Zyglis's picture (Fig. 7) presents a woman that will be easily identified by most viewers as Rosie the Riveter, as it has her same face, her posture and stance, and she is uttering the same slogan Rosie made popular: "We can do it!"; nevertheless, in this case, her polka-dot hair kerchief is not red but grey, like her uniform, which is not a factory uniform but the army one. She is also carrying a rifle on her back and there is a badge on her sleeve which says "Front lines".

Since Rosie appears as a woman in the military, as the title indicates, the implicated premise that the readers/viewers will most probably infer is that brave Rosie is not asking her fellow women to support men on the home front, but claiming their right to combat on the 'real' front.

In Fig. 8, Benson's cartoon still recalls Rosie, it is her same posture and stance, but she has gone a step further; instead of wearing her kerchief, she is wearing a military helmet with the female symbol on it. Her facial features seem to be those of an Afro-american woman, one belonging to a minority. And she is more assertive, instead of "We can do it!", she claims bravely and triumphantly: "You've finally recognized that I've got the guns to do it!". It is not only that women can, but that they have made society recognize that they can. Notice the use of "the guns to do it"; notice also the big flag in the foreground and the flag on her sleeve. She feels a true patriot.

The implicated premise or contextual assumption derived from the verbal clues in Benson's picture is that there is a ban forbidding women to go into combat which women are fighting against. They look proud of having proved their courage and capacity to do so.

The obvious implicated conclusions from both cartoons are that they stand as vindications for women's right to go into combat on the front.

3.1.3. 'Rosie': from a hard-working worker to a brave supporter of minority rights
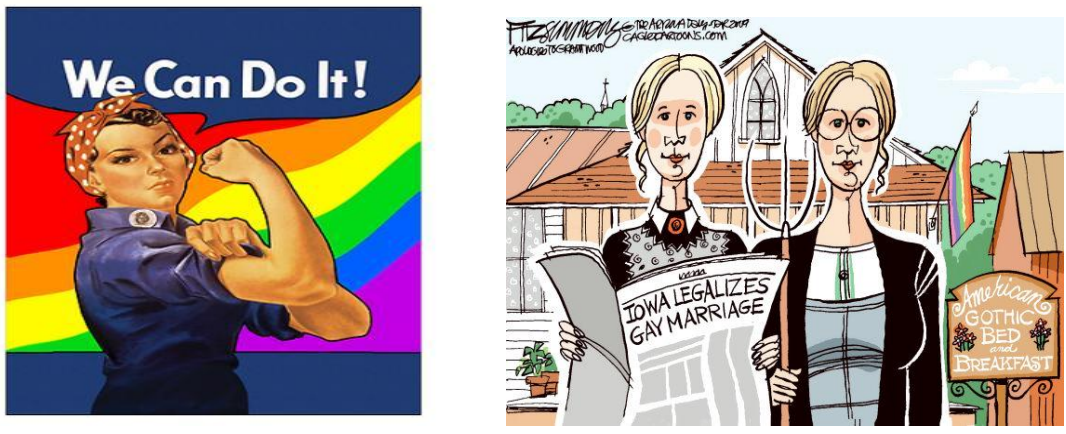

Figure 9. 'Rainbow Rosie the Riveter'

URL: <http://www.cafepress.es/+rainbow_rosie_small_poster,574338489>

Figure 10. 'Gay Marriage in Iowa', by David Fitzsimmons, U.S. The Arizona Daily Star (04/08/2009)

Fig. 9 presents an ecophanic representation in which the intensity of Rosie's iconic-verbal message is used as a means to support minority rights (implicated conclusion). The clue for this interpretation is the use of the rainbow flag as a background for the picture (explicit content); since the 1970s, when the social movement to achieve equal rights and marriage for same-sex couples arose in the US, it is the symbol of gay and lesbian pride (implicated premise). This issue was hotly debated during the 1990s and Congress enacted the Defense of Marriage Act in 1996, prohibiting federal 
recognition of these marriages.

In 2003 Massachusetts allowed gay marriage and several other states followed their footsteps. Public opinion in favour of its legalization has been increasing during the first decade of the 21st century and now, since October 2014, after a Supreme Court ruling, gay marriage is legal all over the US. Since 26 June 2015, all the US states are required by the Supreme Court to recognize gay marriage. While Massachussetts was the first state to legalize gay marriage, Iowa, with a population of only 3 million people, was the first Central state to do so.

Inspired by this, the editorial cartoonist David Fitzsimmons created an amusing echoic representation of Grant Wood's 'American Gothic' (Fig. 10) for The Arizona Daily Star entitled 'Gay Marriage in Iowa' (04/08/2009). The subtitle seems to be intended to guide the addressee's process of interpretation by strengthening inferences that otherwise might have seemed weak; Iowa is described as 'American Gothic bed and breakfast', which invites the audience to perceive it as an idyllic place where gay couples can live without pressures of any type.

The explicit content of the picture presents an echoic representation of the well-known 'American Gothic', but, on this occasion, two women are the protagonists; there is a rainbow flag on the house in the background, which is nicely painted and decorated with plants. The implicated premise or contextual assumption is that, since one of them is reading a paper with the headline "Iowa legalizes gay marriage", they must be a gay couple themselves, probably living together in that nicely decorated house. As a result, the addressees will most probably gather from the contextual implication or implicated conclusion that same-sex marriage has recently been legalized in that state.

3.1.4. 'Rosie': from an industrious worker to a brave vindicator of women's rights

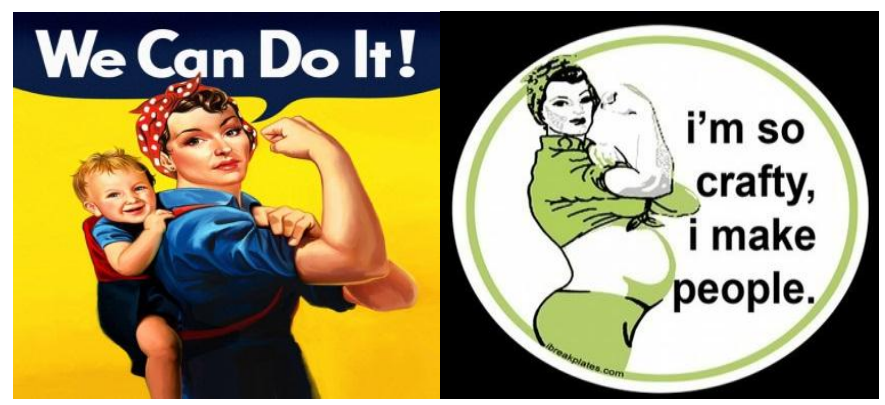

Figure 11. 'Recognizing Women's Contributions on Labor Day' (2013)

URL: <http://ursulinemagazine.com/tag/rosie-the-riveter/>

Figure 12. 'I'm so crafty, I make people' 'Pregnant Rosie the Riveter'

URL: <http://photobucket.com/images/rosie\%20the\%20riveter>

Other echoic evocations of 'Rosie the Riveter' are designed in order to highlight the important social role women play as mothers and caregivers of children. Women carry the burden of an unpaid, unnoticed and thankless job. Figures 11 and 12 demand policies allowing the conciliation of family life and work life.

In Fig. 11, the explicit content shows Rosie carrying a baby on her back. In Fig. 12, a green and white reproduction of Rosie, in what looks like a sticker, appears as being pregnant; the verbal clues are also different: "i'm so crafty I make people".

The implicated premises are that the child on her back, and obviously that the one in her womb, are Rosie's children. Her aspect indicates that she is a worker, and her vindicative attitude and her words will most probably be intended to mean that it is really tough work to be a mother-worker; but they are so crafty that they can carry out the most difficult and responsible tasks, if they can "make people", there will be nothing they will not dare do.

The implicated conclusions gathered from both cartoons show how women not only need to conciliate family and work, but also to even demonstrate in the 21 st c. that they are able to do both things very well.

As an example of a "dissenting echoicity", the following advertisement by Swiffer Bissell (Fig. 13) employs Rosie's icon in a self-interested way, relating the original slogan "We can do it" to the carrying out of domestic work. In fact, the verb 'do' is used as a substitute for this: "We can do domestic work better with the help of Swiffer Bissell steam boost". Feminist reactions were obviously immediate, since the advertising company seemed to contribute to the perpetuation of traditional outdated roles. The issue was widely debated in the social networks and the firm was obliged to correct themselves and explain their intentions. 


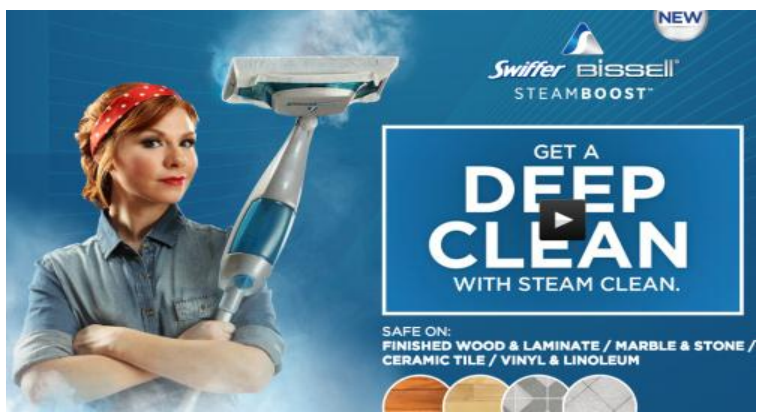

Figure 13. 'Swiffer Bissell Steam Boost' ad (2013)

Many celebrities have posed characterized as Rosie in favour of women's rights. Singer Beyoncé used this image as a 21st c. Rosie for her Instagram profile. The same as Christina Aguilera and Pink in their music videos, five Grammy awards winner Kelly Rowland, actress and model Alexis Bledel, entrepreneur Kris Jenner or even actor Daniel Craig and rapper Kanye West also did. Particularly relevant is Michelle Obama's image as Rosie the Riveter, appearing as a referent for black women.

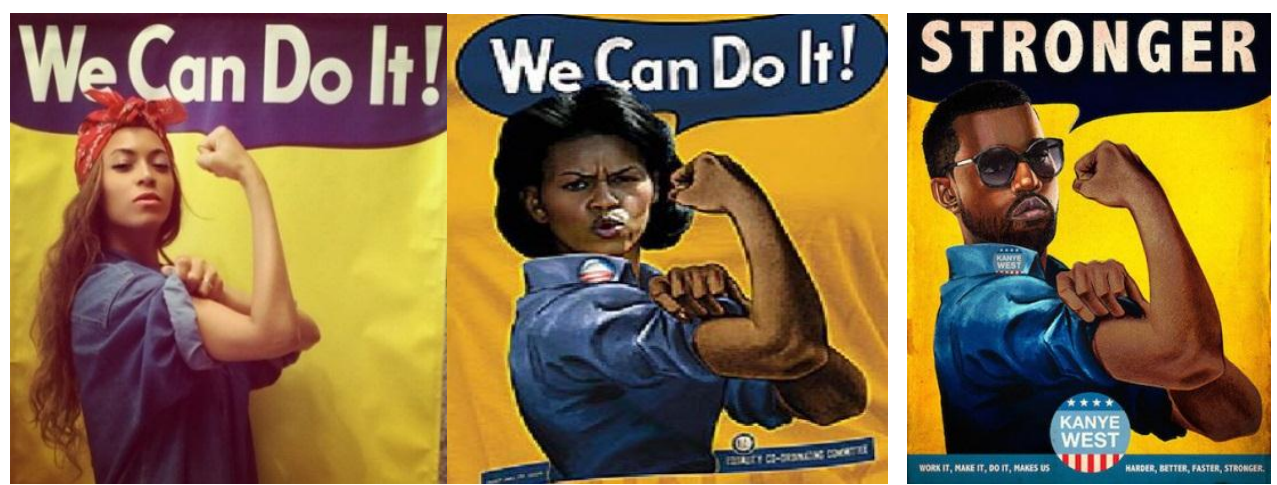

Figure 14. Beyoncé as Rosie the Riveter

URL: <http://nymag.com/thecut/2014/07/bey-can-do-it-beyonc-goes-rosie-the-riveter.html>

Figure 15. Michelle Obama as Rosie the Riveter

URL: <http://www.thefrisky.com/2009-03-05/michelle-obama-is-the-new-rosie-the-riveter/>

Figure 16. Kanye West by David Redon

URL:<http://uk.complex.com/style/2014/04/kanye-west-as-rosie-the-riveter-and-other-reinterpreted-vintage-ads-by-dav id-redon>

Many women even feel proud to wear Rosie's indelible image on their own bodies as a real physical sign of women's empowerment. Body art has recently begun to be conceived as an art form with a high cultural and anthropological value.
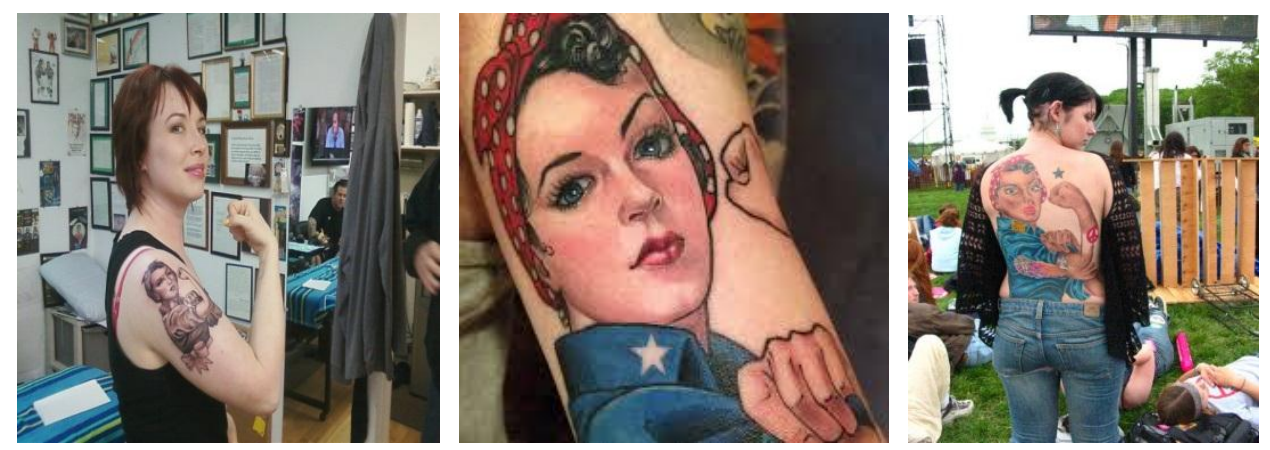

Figures 17, 18 \& 19. 'Rosie the Riveter'. Body art.

URL: 〈http://media-cache-ec0.pinimg.com/736x/ed/70/d6/ed70d6132c21a273086cd40c5cc06091.jpg〉 


\subsection{Ecophanic representations of the long-suffering and eccentric artist Frida Kahlo}

The Mexican artist Frida Kahlo (1907-1954) ${ }^{8}$ became popular at a time when only a few women achieved success. Although she was practically unknown outside Mexico during her lifetime, since the 1980s she has become one of the most highly valued artists in Latin America, and she has aroused passions among many of her followers, who worship her in a kind of Fridomania or Kahloism (Zacharek, 2002). Now she is considered to be one of the most charismatic women in history, and a paradigm of personal achievement perceived as an artistic icon and a symbol of feminism.

Kahlo reflected her vital experience in her artworks through a constructed and planned image of herself, a cultural product based on her artistic ideas, her own personality and her deep Mexican roots. She maintained a continued struggle against physical and emotional pain throughout her life, and showed her intense capacity to bare her feelings and suffering in her paintings9. Her original and transgressive artistic career revealed her as being an independent, determined and autonomous woman, both a heterosexual and homosexual icon (Salber, 2006). Free from social conventions and gender prejudices, she had an androgynous physical appearance and appeared moustachioed and with thick united eyebrows; this has been recurrently repeated in her echoic representations through time.

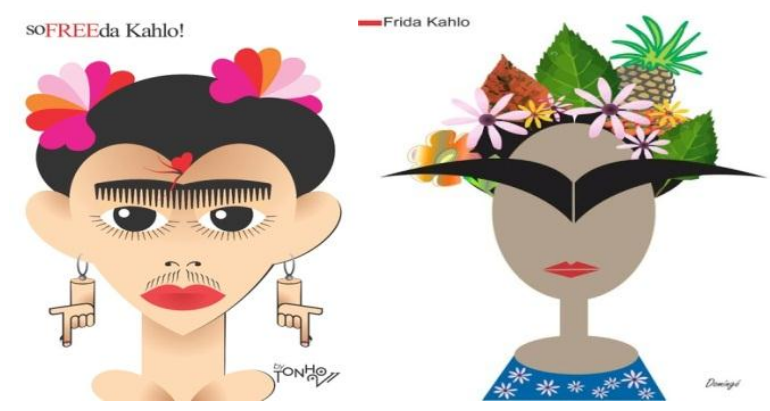

Figures $20 \& 21$. Frida Kahlo

URL: <http://it.toonpool.com/cartoons/Frida\%20Kahlo_119189>

URL: <http://caricaturaszonacaustica.blogspot.com.es/2013/07/frida-kahlo.html>

\subsubsection{Frida's life as an art: her tortuous relationship with Pedro Rivera}

Most of Kahlo's paintings were self-portraits that showed her inner feelings of hatred, anger, panic, loneliness, or sadness (Bartra, 2005). They served as public confessions that shattered taboos associated with the body, female sexuality or abortion. She brought together popular, religious and traditional Mexican symbols, becoming a visual precedent of 'magic realism' thanks to the interior revolution expressed in her works, as opposed to her husband's 'external' topics.

Kahlo and Diego Rivera, the most popular Mexican revolutionary painter, had an intense though stormy and atypical relationship full of quarrels, infidelities and reconciliations. This pair of intellectuals of different ages and personalities had no children.

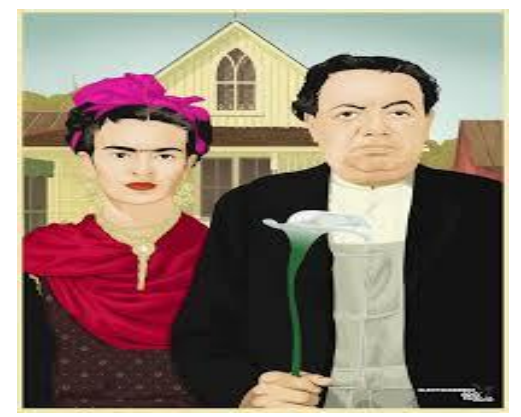

Figure 22. 'Mexican Muralist Gothic' by Elroy Gullermo (2014)

URL: <http://www.pinterest.com/pin/71213237830670731/>

In Fig. 22, Frida Kahlo and Diego Rivera represent the 'American Gothic' family in an echoic and parodic re-creation of Wood's painting by a contemporary cartoonist, Elroy Gullermo.

The non-verbal explicit content of the picture shows many similarities with the original painting by Wood: the background is the same, the characters are wearing the same clothes as the original protagonists, and they have the same 
stance and grave penetrating gazes. The new elements are Frida's traditional and very personal accessories (shawl, earrings, necklace and hair scarf), and the flower in Rivera's right hand substituting the original hayfork. It is an Alcatraz flower or white calla lily, a flower recurrently appearing in many of Rivera's paintings ("El porteador de flores", "Día de las flores" or "Desnudo con Alcatraces") and which he endowed with a heavy symbolic weight.

The author of this parodic image purposely exploits these contextual effects in an attempt to link both popular families, the American Gothic one and the Mexican one, and, at the same time, set a sharp contrast between them. This would most probably awake all sorts of interpretations by the addreessees, from the lightest ones considering it as pure entertainment, to the more thoughtful and reflective ones.

3.2.2. Frida standing by herself

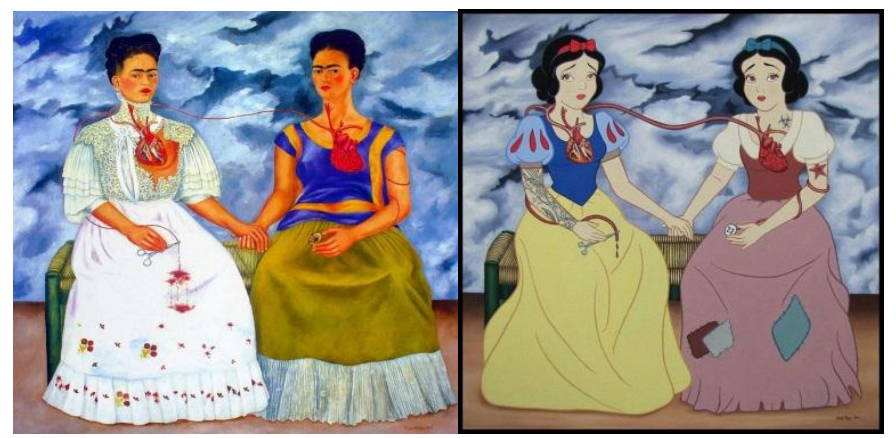

Figure 23. "Las dos Fridas" ('The two Fridas') by Frida Kahlo (1939)

Figure 24. "Disney Frida" by José Rodolfo Loaiza Ontiveros (2014)

URL: <http://www.artnau.com/2014/03/jose-rodolfo-loaiza-ontiveros/>

Brushstrokes of reality, pain, cruelty and dualism pervade Frida Kahlo's paintings. In her 1939 self-portrait, "Las dos Fridas" ("The two Fridas"), against a stormy background Kahlo depicts the maelstrom of emotions surrounding her marital crisis and painful separation from Diego Rivera. She holds her own hand for, in pain, she seems to have only one companion, i.e. herself. The Frida on the right looks like a typical Mexican woman in her tehuana traditional dress and holds an amulet (Diego's portrait as a child). Her heart is broken for she has been spurned by Diego. On the other hand, the Frida on the left looks like a more cosmopolitan woman, her heart is healthy, and she is trying to heal its wounds and stop the bleeding with a pair of surgical scissors.

Loaiza-Ontiveros's echoic picture turns the two Fridas into two Walt Disney's characters. The stereotypical portrait of early 20th c. women that was presented to children and which Loaiza seems to be criticizing is that of Snow White as a ragged housewife and whose role consists of doing the housework. She is virginal and submissive, and does not rebel agains her beautiful, wicked mother-in-law. On the other hand, the Snow White on the left shows a tattoo on her right arm as a sign of rebellion, wears more impeccable clothes and tries to prevent her painful bleeding with the aid of a pair of surgical scissors like the original Frida in her portrait.

The echophanic re-creation by Loaiza-Ontiveros deliberately combines elements that do not tend to appear together, in order to provoke greater contextual effects on the receivers. It is a children's character that represents two types of real women, the subjugated one and the one that tries to escape from this role. The receivers are expected to grasp all these meanings and probably reflect on women's role in society.

\subsection{3. "Lo personal es político" (Personal issues are also political ones)}

According to Alario Trigueros (2008), every single painting by Frida Kahlo was connected to a person she knew or to a personal experience, in such a way that her own misfortunes, wishes, fears and joys were publicly exposed, thus bringing to life the slogan that was brandished some years later by radical feminism, i.e. personal issues are also political ones.

As an active member of the Mexican communist party her feminist action could be embedded into the context of vindications demanded some time later by post-colonial feminism. She was greeted as an intelectual who courageously defended political causes she believed in. In her work entitled "El marxismo le dará salud a los enfermos" (1954) ("Marxism will make the sick healthy"), she discloses her political interests, as well as her deepest personal frustrations. 


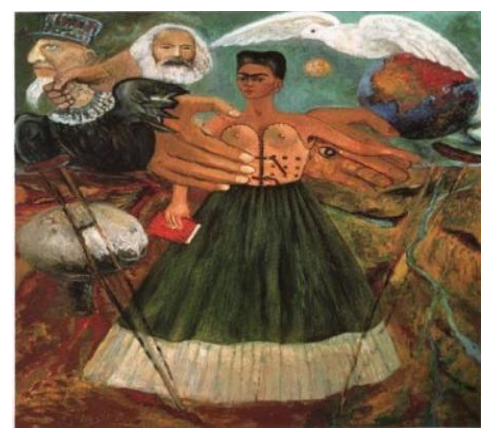

Figure 25. "Marxism will make the sick healthy" by Frida Kahlo (1954)

The above is reflected in the pervasive symbolism that occurs in the comic strips shown below.

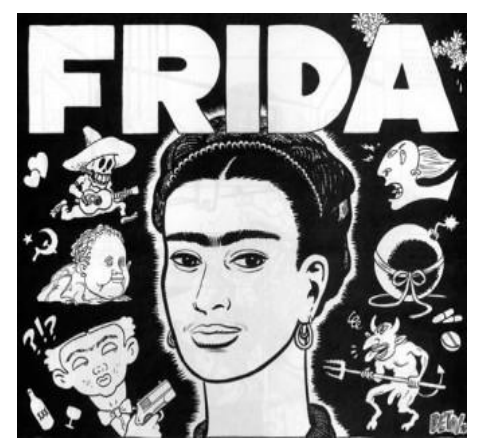

Figure 26. 'Frida Kahlo' by Gilbert Hernández (Love \& Rockets, vol.1, p. 28, Dec. 2007)

URL: 〈http://www.comicsreporter.com/index.php/briefings/blog_monthly/2007/12/>

Towards the end of the 80's Jaime \& Gilbert Hernández, the authors of the popular comic strip Love and Rockets, presented Kahlo's life in a series of most attractive samples. Fig. 26 shows Gilbert's evocation of her figure with her name in large capital letters and surrounded by symbols that most of the audience would easily recognize as inherent parts of her life: her Mexican roots, the men in her life, her husband, lovers, friends and admirers (Rivera, Leon Trotsky, André Breton, Picasso, etc.). In brief, this re-creation pays tribute to a non-conventional inspiring women Breton described as "a ribbon around a bomb".

\subsubsection{Frida goes pop}

In recent statements to the Mexican newspaper La Jornada, the Italian art critic Achille Bonito Olivo said about Frida Kahlo: "Era una acróbata de la pintura. Transformó su retrato en un icono" (18/03/2014) ("She was an acrobat of painting. She transformed her portrait into an icon"). Her emblematic life and her works have also inspired many books and two films, "Frida, naturaleza viva" (1984, directed by Paul Leduc) and "Frida" (2002) starring Mexican actress Salma Hayek as Frida, and directed by Julie Taymor. So great is the wealth of echoic images emerging from her, many of them kitsch Kahlo, that she has become a cult object ${ }^{10}$.
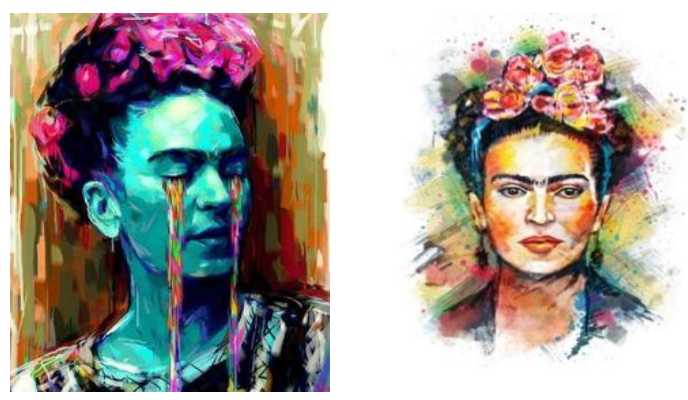

Figure 27. ‘Frida Kahlo' by Natmir Lura (Denmark) (2014)

URL: <https://www.pinterest.com/pin/16747829840310888/>

Fgiure 28. 'Frida Kahlo' by Tracie Andrews (Great Britain) (2014)

URL: <http://matadornetwork.com/es/viva-frida-artistas-de-todo-el-mundo-retratan-al-icono-mexicano/> 
Frida Kahlo also had her own Google doodle on her 103 birthday anniversary.

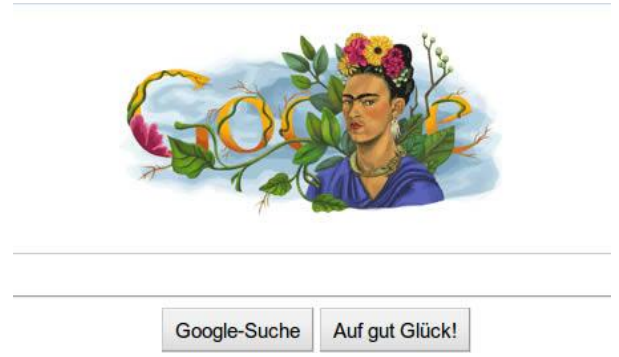

Figure 29. Frida Kahlo’s Google doodle (2010)

URL: zhttp://www.oddee.com/item_97218.aspx>

\subsection{The fusion of two inspiring feminist models of women: Frida the Riveter}

The two models of women analysed, Rosie the Riveter and Frida Kahlo, have both inspired people of different times and places. Symbolically enough, Korean-American artist Maria Kane, whose artwork is devoted to the timeless strength of iconic women, blends the power of these two different though equally inspiring icons, the industrious and hard-working Rosie the Riveter and the long-suffering and eccentric Frida Kahlo. In this fusion Frida seems even more powerful and self-assured.

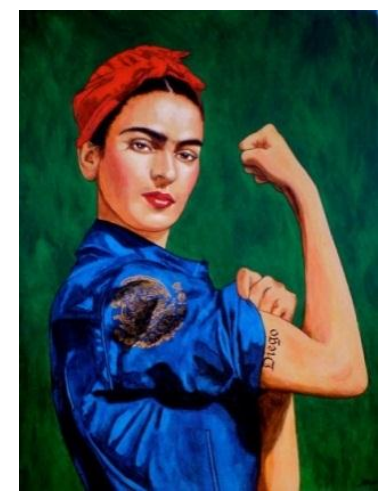

Figure 30. 'Frida the Riveter' by Maria Kane (2013)

URL: <http://pocho.com/feminist-mashup-painting-results-in-stunning-frida-the-riveter-toon/>

\section{Conclusions}

Art is of an inherently symbolic and referential nature which, as Eco put it (1973), functions and acquires meanings apart from their relationship with their original real referent. In the symbolic construction of meaning, interpreters make mental associations of a metaphorical kind, not necessarily established on the basis of an underlying code (Sperber \& Wilson, 1986, 1995). In the case of multimodal texts combining verbal and non-verbal clues, non-verbal elements become a source of information that immediately connects to the addressees's cognitive schemas guiding them in the formation of their hypotheses (Tanaka, 1994; Rivas-Carmona, 2014).

According to Sperber and Wilson's ostensive-inferencial model of communication, the addresser's communicative intention comes to fruition by means of logic stimuli (input) that will trigger some contextual effects on the addressees. The receivers interpret this input following a process of inference based on both the explicit content and the implicit or implicated meaning.

The present paper has dealt with multimodal iconic representations endowed with an 'echoic nature', i.e, with the power to give rise to new images inspired in them. Two inspiring images of archetypal women representing two feminist models, namely Rosie the Riveter and Frida Kahlo, have been analysed from the pragmatic-cognitive perspective of Sperber \& Wilson's Relevance Theory $(1986,1995)$, that is considered to be one of the most effective approaches for studying multimodal and iconic messages.

As the echoic representations analyzed have shown, the relevant images of these two iconic women have been kept in the memory of audiences belonging to different contextual locations and times, and their power of evocation is so great that they will continue to acquire new meanings for the producers and interpreters of new social, cultural and temporal contexts in the future. What is more, these referents may be blended together, like those of Rosie and Frida (Fig. 30), and take on new lives of their own. 


\section{References}

Alario Trigueros, M. T. (2008). Arte y feminismo. San Sebastián, Spain: Editorial Nerea.

Balsera, F. M. (2012). Variaciones pragmáticas del discurso electoral. El caso de "Hope" de Barack Obama. Odisea: Revista de Estudios Ingleses, 13, 129-155.

Balsera, F. M. (2013). Pragmática ecofánica del contradiscurso artístico "oportunista" en política. Hikma: estudios de traducción, 12, 23-46.

Bartra, E. (2005) Frida Kahlo: mujer, ideología y arte. Barcelona, Spain: Icaria.

Benne, K. D. (1969). Contemporary irrationalism and the idea of rationality. Studies in Philosophy and Education 6(4). http://dx.doi.org/10.1007/BF00372691

Carmen López Alonso en su artículo del (04/08/2014) en el periódico "El País" titulado "Rosie la Remachadora: la verdadera historia que esconde el icono del feminismo"

Cassirer, E. (1944). An Essay On Man. An Introduction to a Philosophy on Human Culture. New Haven, CT: Yale University Press.

Cassirer, E. (1953). The philosophy of symbolic forms. New Haven, CT: Yale University Press.

Colman, P. (1998). Rosie the Riveter: Women Working on the Home Front in World War II. New York, NY: Crown Publishers.

Corn, W. M. (1983). The Birth of a National Icon: Grant Wood's "American Gothic". Art Institute of Chicago Museum Studies 10, 252-275. http://dx.doi.org/10.2307/4104340

Dawson, M. R. W. (1998). Understanding Cognitive Science. Malden, MA: Blackwell.

Eco, U. (1968). La struttura assente. La ricerca semiotica e il metodo strutturale. Milan, Italy: Bompiani.

Eco, U. (1973). IL segno. Milan: Isedi.

Gadamer, H. G. (1986). The Relevance of the Beautiful and Other Essays. Cambridge, U.K:: Cambridge University Press.

Montero Pachano, P. C. (2005). Cassirer y Gadamer: el arte como símbolo. Revista de filosofía (Chile) 51, 3, 8-9.

Morris, Ch. (1971). Writings on the General Theory of Signs. The Hague: Mouton. http://dx.doi.org/10.1515/9783110810592

Peirce, Ch. S. (1958). Selected writings. New York, NY: Dover Publications.

Peirce, Ch. S. (1992-1998) The Essential Peirce, 2 vols. N. Bloomington, IN: Indiana University Press.

Pinker, S. (2007). The Stuff of Thought: Language as a Window into Human Nature. New York, NY: Viking.

Rivas-Carmona, M. M. (2014) Cartooning for Gender Equality: A Multimodal Expression of 'Humour' and 'Vindication'. Research on Humanities and Social Sciences, 4(24), 8-20.

Salber, L. (2006). Frida Kahlo. Madrid: Editorial Edaf.

Sobel, C. P. (2001). The cognitive sciences: An interdisciplnary approach. Mountain View, Calif.: Mayfield.

Sperber, D. (1975). Rethinking symbolism. Cambridge, UK: Cambridge University Press.

Sperber, D. (1984). Verbal irony: Pretense or echoic mention?. Journal of Experimental Psychology, 113(1), 130-136. http://dx.doi.org/10.1037/0096-3445.113.1.130

Sperber, D. (1996). Explaining culture. A naturalistic approach. Oxford: Blackwell.

Sperber, D., \& Wilson, D. (1986, $19952^{\text {nd }}$ revised ed.). Relevance: Communication and Cognition. Oxford: Blackwell.

Tanaka, K. (1994). Advertising language. A pragmatic approach to advertisements in Britain and Japan. London: Routledge.

Thagard, P. (1996). Mind: Introduction to Cognitive Science. Cambridge, Mass.: The MIT Press.

Weinberg de Magis, L. (1998). Dan Sperber y los procesos de simbolización. Textos de crítica y revisión bibliográfica preparados por el Proyecto ensayo, simbolismo y campo cultural. (Proyecto CONACYT1000-PH). Mexico: Cuadernos E.S.C.

Wilson, D., \& Sperber, D. (2004). Relevance Theory. In Horn, L.R. \& Ward, G. (eds.) The Handbook of Pragmatics. Oxford: Blackwell, 607-632. 
Zacharek, S. (2002). Mucho más que un símbolo feminista. The New York Times. http://edant.clarin.com/diario/2002/10/02/c-00611.htm

\section{Notes}

Note 1. Symbolic thinking probably constitutes the most important difference between human beings and the rest of animals, and plays an essential role in the former's activities. The term refers to the human capacity to create and manipulate a wide variety of symbolic representations. This unique feature allows humans not only to transmit information from one generation to another, but also to learn, even without a direct experience of reality, and develop a culture.

Note 2. See Montero Pachano's article on this matter (2005).

Note 3. Wilson (2000: 411) defines meta-representation as the "representation of another representation"; these may be similar or opposed, even if they come from the same source.

Note 4. See "36 Pop Cultural Reinventions Of The American Gothic Painting. Probably the most parodied painting on earth"

URL: <http://www.buzzfeed.com/angelameiquan/36-pop-cultural-reinventions-of-the-american-gothi-70fn

Note 5. See the lyrics of the song in: <http://lyricsplayground.com/alpha/songs/r/rosietheriveter.shtml>

Note 6. The term "empowerment" was coined during the World Women Conference in Beijing in 1995 in order to refer to the increase in women's participation in decision-making processes and access to power.

Note 7. From the very beginning of the conflict, six million women volunteered to work in the factories. 37.000 of them died in industrial accidents and 210.000 ended up mutilated or disabled. In October 2000, under Bill Clinton's office, the building of an in memoriam monument at the Inside Front of WW II National Park was approved. There is also a splendid collection of photographs of these women workers of the 1940s at the Library of Congress.

The image of women workers substituting men who were on the front during WW II is an interesting phenomenon that also took place in other countries. This is, for instance, the case of 'Ronnie, the Bren Gun Girl' in Canada and "land girls" in the UK in agriculture.

Note 8. She was the daughter of the German photographer Wilhem Kahlo and the Mexican Matilde Calderón. She died at the age of 47 , after having had a leg amputated due to it being affected by gangrene.

Note 9. She caught polio when she was a child and had a serious accident in her youth, making surgery necessary more than thirty times, preventing her from having any children.

Note 10. See "Frida Kahlo, a pop icon who has gone on conquering us with her work" (June 17, 2015)

URL: <http://www.nytimes.com/2015/05/10/universal/es/frida-kahlo-conquista-a-eeuu.html>

\section{(cc) $\mathrm{EY}$}

This work is licensed under a Creative Commons Attribution 3.0 License. 